Hard Work 
This page intentionally left blank 


\title{
Hard Work
}

Remaking the American Labor

Movement

\author{
Rick Fantasia \\ Kim Voss
}

UNIVERSITY OF CALIFORNIA PRESS

Berkeley Los Angeles London 
University of California Press

Berkeley and Los Angeles, California

University of California Press, Ltd.

London, England

(C) 2004 by the Regents of the University of California

Library of Congress Cataloging-in-Publication Data

Fantasia, Rick.

[Des syndicats domestiquâes. English]

Hard work : remaking the American labor movement /

Rick Fantasia, Kim Voss.

p. $\mathrm{cm}$.

Revised and enlarged edition of Des syndicats domestiquâes, which was originally written in English, then translated into French and published in Paris by Raisons d'Agir, 2003.

Includes bibliographical references and index.

ISBN O-520-24OI3-8 (cloth : alk. paper)ISBN O-520-24090-I (pbk. : alk. paper)

I. Labor movement-United States. 2. Labor unionsSocial aspects - United States. 3. Labor unions-United States-Management. 4. Industrial relations-United States. 5. Bureaucracy-United States. I. Voss, Kim. II. Title.

HD6508.F235I3 2004

33 I.88'0973-dc22

2003022988

Manufactured in the United States of America
$\begin{array}{llllllllll}\text { I3 } & \text { I2 } & \text { II } & \text { IO } & 09 & 08 & 07 & 06 & 05 & 04\end{array}$

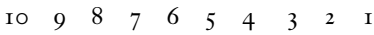

The paper used in this publication meets the minimum requirements of ANSI/NISO Z39.48 - I992 (R I997)

(Permanence of Paper). $@$ 
For Adele and Camille, and for Eli and Fulian 
This page intentionally left blank 